\title{
РЕЦЕНЗИИ
}

\section{П.М. Морхат}

\section{РЕЦЕНЗИЯ НА МОНОГРАФИЮ: БЕГИШЕВ И.Р., ХИСАМОВА З.И. ИСКУССТВЕННЫЙ ИНТЕЛЛЕКТ И УГОЛОВНЫЙ ЗАКОН. М.: ПРОСПЕКТ, 2021. 11,5 авТ. Л.}

\begin{abstract}
Представлена рецензия на монографию «Искусственный интеллект и уголовный закон». Новизна рецензируемой монографии заключается в том, что в основу исследования положен междисциплинарный подход, позволивший обеспечить достаточно серьезную глубину проведенной работы. В монографии детально раскрываются проблемы соотношения уголовно-правовых норм и деликтов, совершаемых с участием искусственного интеллекта и робототехники.
\end{abstract}

Ключевые слова: искусственный интеллект, робот, робототехника, иифровые технологии, информационные технологии, правосубъектность, электронное лицо, уголовное право, уголовный закон, криминология, криминологический риск.

Цифровизация, ознаменовавшая Четвертую промышленную революцию (Индустрию 4.0), неразрывно связана с технологией искусственного интеллекта. Искусственный интеллект крепко и надолго занял место в числе основных технологических инноваций и стал неотъемлемой частью нашей жизни. Аналитики по всему миру единогласно называют искусственный интеллект ключевым технологическим трендом [1]. Внедрение искусственного интеллекта позволило не только с большой скоростью обрабатывать огромные объемы данных, но и давать высокоточные прогнозы развития для сложных систем и явлений. Все активнее он применяется и для решения глобальных экологических и социальных проблем человечества. Например, совсем недавно Советом Европы был опубликован обзор, посвященный искусственному интеллекту в качестве инструмента поддержки борьбы с вирусной пандемией, поразившей весь мир с начала 2020 г. [2].

В апреле 2018 г. аналитическое агентство Gartner опубликовало исследование, согласно которому в 2017 г. компании по всему миру получили \$692 млрд дохода, а к 2022 г. выгода от применения искусственного интеллекта будет измеряться почти \$4 трлн [1].

Вместе с тем развитие технологии искусственного интеллекта и робототехники как формы его материального проявления ставит серьезные вызовы перед правом в целом. Особо остро проблема встает для сферы уголовного законодательства, которая является крайней формой государственного реагирования на общественно опасные проявления и деяния. И представленная на рецензирование монография [3] представляет собой первое комплексное монографическое исследование, посвященное проблемам синергии технологии искусственного интеллекта и уголовного закона.

Эта монография практически завершает цикл работ авторов, посвященных исследованию уголовноправовых и криминологических аспектов применения искусственного интеллекта в преступных целях [4-7] и комплексного теоретико-прикладного анализа основ- ных современных доктрин, посвященных регулированию искусственного интеллекта и робототехники [8-14].

$\mathrm{B}$ настоящий момент существует пустое пространство между уголовным правом в частности и всем блоком криминальных наук в общем и развивающейся сферой искусственного интеллекта. Хотя запрос на регулирование уже существует. Достаточно вспомнить инциденты с беспилотными автомобилями либо с производственными роботами, приведшие к гибели людей. И это только начало. Развитие технологии будет стимулировать потребность разрешения вопросов юридической ответственности за вред, причиненный действиями роботов и (или) искусственного интеллекта, а также их правовой автономии, т.е. наделения правосубъектностью.

Отмечу, что мне импонирует положенный авторами в основу исследования междисциплинарный подход, позволивший обеспечить достаточно серьезную глубину проведенной работы. Так, при исследовании понятия «искусственный интеллект» авторы не ограничились исключительно доктринальными толкованиями, приведенными уже в юридической литературе. Авторам удалось на достаточно высоком профессиональном уровне обобщить обширное поле концепций, позиций и подходов, нередко оппонирующих друг другу. Они обратились к актуальным исследованиям в области кибернетики, информатики, психологии, философии, что в совокупности с анализом легальных толкований позволило сформулировать достаточно подробное и заслуживающее внимания авторское определение, во многом коррелирующее уже с имеющимися в литературе, в том числе и с моим, и одновременно обладающее отдельными преимуществами, особенно в условиях, когда единое понятие искусственного интеллекта пока не выработано ни в научной доктрине, ни на законодательном уровне.

Кроме того, авторы озадачились вопросом семантического анализа понятий «искусственный интеллект» и «робототехника» как с точки зрения наук технического цикла, так и юридического, что весьма ценно для меж- 
дисциплинарных исследований. Прикладная значимость такого анализа определяется также тем, что проведенный авторами «водораздел» указанных понятий позволит снизить существующую на сегодняшний день в научной литературе, особенно юридической, путаницу технологических понятий.

Необходимо заметить, что отдельный блок исследования посвящен вопросам международно-правового регулирования внедрения искусственного интеллекта, что вполне оправданно, так как проблема правосубъектности роботов и искусственного интеллекта находится в поле зрения большинства международных организаций. Наделение искусственного интеллекта квазигражданским статусом поднимает глубинные вопросы, в том числе связанные с правами человека.

Достаточно интересной для исследователейюристов всех отраслей права представляется часть исследования, посвященная этическим и вытекающим из них криминологическим рискам применения искусственного интеллекта. Опираясь на исследования зарубежных авторов, авторы предлагают свою интерпретацию и классификацию криминологических рисков применения искусственного интеллекта [4].

В работе прослеживается достаточно стройная логика изложения материала. Так, описав имеющиеся риски применения искусственного интеллекта, авторы переходят непосредственно к проблемам наук криминального цикла. В частности, детально раскрываются проблемы соотношения уголовно-правовых норм и деликтов, совершаемых с участием робототехники и искусственного интеллекта. Здесь следует отметить, что авторы не только выносят на обсуждение научной общественности имеющиеся в указанном срезе проблемы, но и предлагают модели их разрешения.

Особый интерес вызывают модели «привлечения искусственного интеллекта к ответственности» при гипотетическом наделении искусственного интеллекта правосубъектностью. Однако следует заметить, что авторы не пускаются в данном аспекте в «кибернетические фантазии», предлагая в корне изменить существующий институт уголовной ответственности, а наоборот, отмечают, что в силу уровня развития существующих систем в настоящий момент такая необходимость отсутствует, но тем не менее в ближайшие десятилетия она может возникнуть.

Полагаю, рецензируемая научно-исследовательская работа соответствует требованиям, предъявляемым к такому виду работ, выполнена на достаточно высоком научном уровне и будет интересна широкому кругу читателей.

\section{ЛИТЕРАТУРА}

1. Top 10 Strategic Technology Trends for 2018. Gartner. URL: https://www.gartner.com/doc/3811368 (дата обращения: 20.09.2020).

2. ИИ и контроль коронавируса Ковид-19. URL: https:/www.coe.int/en/web/artificial-intelligence/ii-i-kontrol-koronavirusa-kovid-19 (дата обращения: 20.09.2020).

3. Бегишев И.Р., Хисамова З.И. Искусственный интеллект и уголовный закон. М. : Проспект, 2021.

4. Бегишев И.Р., Хисамова З.И. Криминологические риски применения искусственного интеллекта // Всероссийский криминологический журнал. 2018. Т. 12, № 6. С. 767-775.

5. Хисамова З.И., Бегишев И.Р. Уголовная ответственность и искусственный интеллект: теоретические и прикладные аспекты // Всероссийский криминологический журнал. 2019. Т. 13, № 4. С. 564-574.

6. Bikeev I.I., Kabanov P.A., Begishev I.R., Khisamova Z.I. Criminological Risks and Legal Aspects of Artificial Intelligence Implementation // In Proceedings of the International Conference on Artificial Intelligence, Information Processing and Cloud Computing (AIIPCC '19). New York : Association for Computing Machinery, 2019. Art. 20. P. 1-7.

7. Bokovnya A.Yu., Begishev I.R., Khisamova Z.I., Bikeev I.I., Sidorenko E.L., Bersei D.D. Pressing Issues of Unlawful Application of Artificial Intelligence // International Journal of Criminology and Sociology. 2020. Vol. 9. P. 1-4.

8. Бегишев И.Р., Хисамова З.И. Искусственный интеллект и робототехника: теоретико-правовые проблемы разграничения понятийного аппарата // Вестник Удмуртского университета. Серия: Экономика и право. 2020. Т. 30, № 5. С. 710-718.

9. Бегишев И.Р., Хисамова З.И. История становления и теоретико-правовые подходы к толкованию понятия «искусственный интеллект» // Алтайский юридический журнал. 2020. № 3 (31). С. 31-38.

10. Хисамова З.И., Бегишев И.Р. Сущность искусственного интеллекта и проблема определения правосубъектности // Вестник Московского государственного областного университета. Серия: Юриспруденция. 2020. № 2. С. 96-106.

11. Хисамова 3.И., Бегишев И.Р. Правовое регулирование искусственного интеллекта // Baikal Research Journal. 2019. Т. 10, № 2.

12. Khisamova Z.I., Begishev I.R., Sidorenko E.L. Artificial Intelligence and Problems of Ensuring Cyber Security // International Journal of Cyber Criminology. 2019. Vol. 13, № 2. P. 564-577.

13. Khisamova Z.I., Begishev I.R., Gaifutdinov R.R. On Methods to Legal Regulation of Artificial Intelligence in the World // International Journal of Innovative Technology and Exploring Engineering. 2019. Vol. 9, № 1. P. 5159-5162.

14. Бегишев И.Р., Хисамова З.И. Искусственный интеллект и робототехника: глоссарий понятий. М. : Проспект, 2021.

Book Review: Begishev, I.R. \& Khisamova, Z.I. (2021) Iskusstvennyy Intellekt $i$ Ugolovnyy Zakon [Artificial Intelligence and Criminal Law]. Moscow: Prospekt

Ugolovnaya yustitsiya - Russian Journal of Criminal Law, 2020, no. 16, pp. 127-129. DOI: 10.17223/23088451/16/24

Petr M. Morkhat, Arbitration Court of the Moscow Region (Moscow, Russian Federation). E-mail: pmorhat@mail.ru

Keywords: artificial intelligence, robot, robotics, digital technologies, information technology, legal personality, electronic entity, criminal law, criminal law, criminology, criminological risk.

The article presents a review of the monograph Artificial Intelligence and Criminal Law. Its novelty lies in the fact that the research the book presents is based on an interdisciplinary approach, which provides for a sufficiently serious depth of the analysis. The book thor- 
oughly reveals the problems of the correlation between criminal law and delicts committed with the use of artificial intelligence and robots. The authors of the book bring the problems in this field up for discussion in the academic community and propose models for their solution. In the opinion of the author of the book review, the monograph makes a significant contribution to the generalization of the prevailing ideas about artificial intelligence in Russian and foreign legal science. The book is intended for experts in the field of artificial intelligence and robotics, scientists, representatives of the judiciary and law enforcement agencies, students, graduate students and teachers of law schools and universities.

\section{References}

1. Gartner. (2018) Top 10 Strategic Technology Trends for 2018. [Online] Available from: https://www.gartner.com/doc/3811368 (Accessed: 20th September 2020).

2. Council of Europe. (2020) AI and control of Covid-19 coronavirus. [Online] Available from: https://www.coe.int/en/web/artificialintelligence/ai-and-control-of-covid-19-coronavirus (Accessed: 20th September 2020).

3. Begishev, I.R. \& Khisamova, Z.I. (2021) Iskusstvennyy intellekt i ugolovnyy zakon [Artificial Intelligence and Criminal Law]. Moscow: Izd-vo Prospekt. (in print).

4. Begishev, I.R. \& Khisamova, Z.I. (2018) Criminological Risks of Using Artificial Intelligence. Vserossiyskiy kriminologicheskiy zhurnal - Russian Journal of Criminology. 12 (6). pp. 767-775. (In Russian). DOI: 10.17150/2500-4255.2018.12(6).767-775

5. Khisamova, Z.I. \& Begishev, I.R. (2019) Criminal Liability and Artificial Intelligence: Theoretical and Applied Aspects. Vserossiyskiy kriminologicheskiy zhurnal - Russian Journal of Criminology. 13 (4). pp. 564-574. (In Russian). DOI: 10.17150/25004255.2019.13(4).564-574

6. Bikeev, I.I. et al. (2019) Criminological Risks and Legal Aspects of Artificial Intelligence Implementation. Proceedings of the International Conference on Artificial Intelligence, Information Processing and Cloud Computing (AIIPCC'19). New York: Association for Computing Machinery. Art. 20. pp. 1-7.

7. Bokovnya, A.Yu. et al. (2020) Pressing Issues of Unlawful Application of Artificial Intelligence. International Journal of Criminology and Sociology. 9. pp. 1-4.

8. Begishev, I.R. \& Khisamova, Z.I. (2020) Artificial Intelligence and Robotics: Theoretical and Legal Problems of Differentiation of the Conceptual Apparatus. Vestnik Udmurtskogo universiteta. Seriya Ekonomika i pravo - Bulletin of Udmurt University. Series Economics and Law. 30 (5). pp. 710-718. (In Russian).

9. Khisamova, Z.I. \& Begishev, I.R. (2020) The History of the Formation of Theoreticaland Legal Approaches to the Interpretation of the Concept of "Artificial Intelligence”. Altayskiy yuridicheskiy zhurnal - Altai Law Journal. 3 (31). pp. 31-38. (In Russian).

10. Khisamova, Z.I. \& Begishev, I.R. (2020) The Nature of Artificial Intelligence and the Problem of Legal Personality Determination. Vestnik Moskovskogo gosudarstvennogo oblastnogo universiteta. Seriya: Yurisprudentsiya - Bulletin of the Moscow Region State University. Series: Jurisprudence. 2. pp. 96-106. (In Russian). DOI: 10.18384/2310-6794-2020-2-96-106

11. Khisamova, Z.I. \& Begishev, I.R. (2019) Legal Regulation of Artificial Intelligence. Baikal Research Journal. 10 (2). (In Russian).

12. Khisamova, Z.I., Begishev, I.R. \& Sidorenko, E.L. (2019) Artificial Intelligence and Problems of Ensuring Cyber Security. International Journal of Cyber Criminology.13 (2). pp. 564-577.

13. Khisamova, Z.I., Begishev, I.R. \& Gaifutdinov, R.R. (2019) On Methods to Legal Regulation of Artificial Intelligence in the World. International Journal of Innovative Technology and Exploring Engineering. 9 (1). pp. 5159-5162.

14. Begishev, I.R. \& Khisamova, Z.I. (2021) Iskusstvennyy intellekt i robototekhnika: glossariy ponyatiy [Artificial Intelligence and Robotics: A Glossary of Concepts]. Moscow: Izd-vo Prospekt. (in print). 